\title{
An Analysis Of The Levels And Patterns Of Shareholder Rights: 1990 - 2006
}

Lal C. Chugh, University of Massachusetts Boston

Joseph W. Meador, Northeastern University

\begin{abstract}
Greater attention is being paid to the issue of shareholder rights and corporate governance, particularly since the scandals of 1990s and 2000s and the stock market decline of the new millennium. This study advances the concept of an optimum level of shareholder rights in corporate governance and analyzes the long-run trends in shareholder rights versus management entrenchment, using the G-Index. This study finds that the level of shareholder rights generally has not increased, despite the legislative and regulatory reforms of the 2000s and contrary to the general perception. Rather, shareholder rights have declined amongst the large, S\&P 500 companies. The paper also finds that there has been a tendency on the part of firms to converge to a median-level/norm of shareholder rights. Evidence further suggests that firms are searching for an optimum level that balances the risks and rewards of greater shareholder rights.
\end{abstract}

Keywords: corporate governance, shareholder rights, and "optimum" governance structure.

\section{INTRODUCTION}

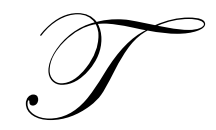

here has been greater awareness of the importance of corporate governance amongst academicians, investors, money managers, governmental institutions, regulatory and professional bodies, lawyers and investment bankers, in the recent past. As a result, greater attention is being paid to developing processes for measuring, monitoring, and quantitatively assessing the corporate governance of firms. Part of the impetus for this greater attention and awareness to measuring corporate governance is attributable to the financial scandals of the 1990s and 2000s and subsequent exposure by the media. These scandals revealed a lack of monitoring by corporate boards, and by regulatory bodies and the financial markets. The sharp downturn in the stock markets in the early $21^{\text {st }}$ century provided further impetus for reform in corporate governance.

\section{THE U.S. PUBLIC CORPORATION - AN IDEAL}

Recent reform efforts in the legislative and regulatory arenas have attempted to rationalize the corporate governance ideal in the US. This ideal embodies the concept that the stockholders own the corporation (Bebchuk, 2006). As a result, they are entitled to share in the profits and future direction of the company through their voting rights. Shareholders elect the Board of Directors which is responsible for appointing senior management (the Csuite). The management becomes the agent of stockholders and is charged with maximizing shareholder wealth. It is generally believed that greater shareholder rights are associated with better corporate governance and consequently greater efforts by management to enhance shareholder wealth. In the parlance of finance literature, agency costs are reduced.

It is generally accepted that there are four standards of shareholder-oriented corporate governance. The first standard is associated with Board independence and performance. In particular, this standard embodies the notions that a substantial number of Board members should be independent of the management, and the Audit and Compensation Committees should be comprised of independent members, with financial expertise on the Audit Committee. Moreover, management decision processes should be transparent and fully disclosed to the Board for evaluation. 
The second standard prescribes equal voting rights for all shareholders, with an absence of dual/multiclasses amongst shareholders. Shareholder Rights should not be abridged by takeover defenses, unequal voting rights, or restrictions on changing by-laws and adding shareholder proposals. The shareholders should have the right to elect the full Board each year, without the limitation of staggered terms for Board members. The shareholders should have the right to an independent nominating committee. Essentially, the second standard implies that the firm's management is not entrenched and can be replaced by the shareholder-elected Board. Furthermore, there are very few restrictions on the rights of shareholders to sell the firm to acquirers.

The third standard of greater shareholder-oriented corporate governance emphasizes transparency of financial information and effectiveness of internal controls. Shareholders should have the right to select auditors, and they can be rotated periodically. The fourth and final standard of shareholder rights ensures that there is an independent committee for determining management compensation, and that compensation is based on performance.

Recent legislation and regulations, such as the Sarbanes-Oxley Act of 2002 (SARBOX), and NYSE regulations, have addressed these four standards, mandating new practices such as required certification of financial statements by the CEO and CFO, disclosure of off balance sheet transactions, Board review of financial controls, regular Board meetings without the presence of management, required shareholder approval of all equity-based compensation, and other similar measures. These changes are thought to have improved the quality of corporate governance by increasing shareholder rights and facilitating the maximization of shareholder wealth, in accordance with the ideal view of corporate governance.

This paper examines the importance of shareholder rights in determining the value of the firm. In addition, it investigates long-run trends in the aggregate measure of shareholders rights in the US over the period 1990 2006, for a large number of publicly-held firms. The study also examines the trends in corporate governance for firms categorized by industry sector and by size of market capitalization.

\section{A THEORY OF OPTIMUM SHAREHOLDER RIGHTS}

It is generally asserted in the literature that greater shareholder rights ensure a higher value of the firm. There are several reasons for this hypothesis. In the first place, litigation costs may be reduced. Greater transparency of governance processes and financial information for investors and acquirers, and protection of minority shareholder rights, may result in less litigation. Secondly, agency costs may be minimized, as independent boards can effectively monitor and supervise management. In addition, appropriate incentives may be put in place which to the performance of management. Thirdly, greater shareholder-oriented corporate governance may be taken as a positive signal for potential investors and analysts. Fourthly, greater transparency may elevate credit ratings, resulting in a lower cost of debt (Ashbaugh-Staife, Collins and LaFonde 2006). Empirical literature demonstrates that greater shareholder rights generally create higher share prices, higher growth rates, higher profitably and lower volatility in share prices (Bebchuk, Cohen, and Ferrell, 2004; Gompers, Ishii and Metrick, 2003; Deutsche Bank, 2004). Gompers, Ishii and Metrick (2003) and Ashbaugh-Staiffe, Collins and LaFonde (2004) also find that cost of equity capital is lower for firms with greater shareholder rights.

On the other hand, it should be emphasized but is often overlooked, that greater shareholder rights entail several important costs. These costs include such factors as (1) disclosure to competitors of strategic and tactical information, (2) slower and less efficient decision-making in a competitive environment, (3) a short-run focus on profitability, resulting in reduced capital investment and R\&D expenditures (Lehmann, Warning, Weigand, 2002), (4) higher career risk and consequently higher CEO compensation (Heffes, 2007 and Hermalin and Weisbach, 2007), and (5) higher agency costs for creditors in light of potential for frequent management turnover resulting in lower credit ratings and higher debt costs (Ashbaugh-Staife, Collins and LaFonde, 2006; Weber, 2006), and (6) attempts by the CEO to distort/disguise proprietary information to protect competitive position.

In contrast to the "Ideal" of corporate governance, an alternative theory of the firm recognizes that the firm is a legal entity and management is expected to be the agent of the firm, not exclusively the agent of the shareholders. Consequently, management has responsibilities to several stakeholders-employees, 
vendors/customers, and society, in addition to the shareholders. According to this theory, management emphasizes long-run value creation of the firm, taking into account the interests of all stakeholders, whereas the shareholders tend to focus on short-run financial results (Stout, 2007 and Economist Magazine, 2007).

In view of the costs of greater shareholder rights, and the other countervailing forces, this study advances the concept that there is an "Optimum" level of shareholder rights which maximizes the value of the firm. This concept is in contrast to the "Ideal" of greater shareholder rights monotonically increasing the value of the firm. This "Optimum" level of shareholder rights is depicted in Figure 1. As shareholder rights increase from some minimum level, the value of the firm is initially enhanced. But, beyond some efficient level of shareholder rights, decision processes and judgment will become constrained, inflexible, and costly. At this stage, further liberalization towards shareholders rights causes the firm to become less responsive to competition and the changing environment and loses entrepreneurial effectiveness, thus potentially reducing the value of the firm.

Figure I: Optimum Shareholder Rights and Firm Value

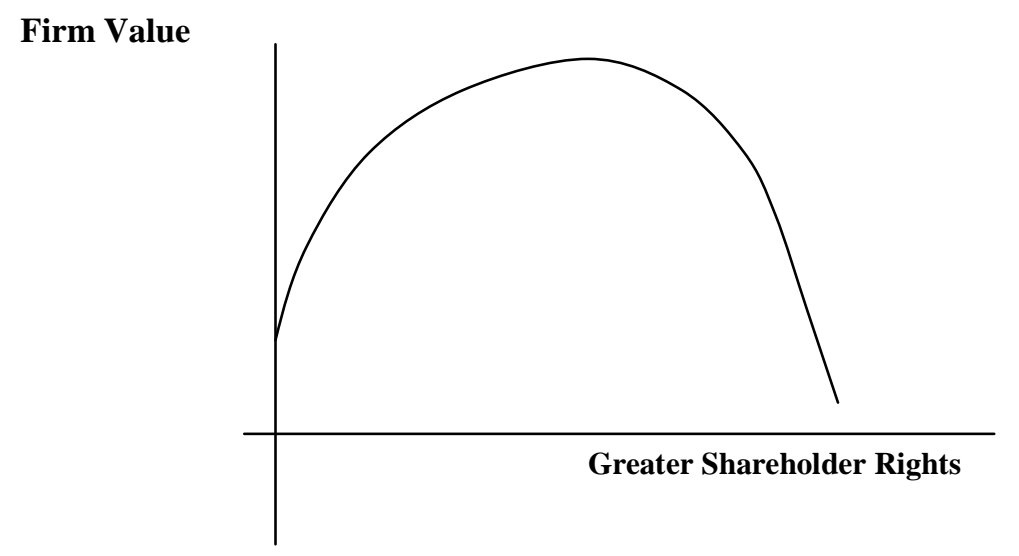

\section{SCOPE OF THE PAPER}

In light of the theory of "Optimum" level of stockholder rights, this paper investigates empirically the level and changes in corporate governance among US firms over the recent past. Previous research studies have focused primarily on cross-sectional performance of corporations associated with selected single or aggregative parameters of corporate governance. These studies also tend to incorporate the assumption that greater shareholders rights are continuously desirable, ignoring a possible "optimum" level of shareholder rights. Thus, alternative theories of governance have not been addressed. The present study focuses on an aggregative measure of corporate governance, which incorporates all four standards of greater shareholder rights. It also focuses on changes in the level of corporate governance by industry sector and by size of market capitalization.

The study measures the level of shareholder rights using the G-Index developed by the Investor Responsibility and Research Center (IRRC) and available at the Wharton Research Data Services (WRDS). The GIndex consolidates twenty-four provisions which limit shareholder rights, as described in Appendix A, on about 1,800 reporting firms. The G-Index varies from 0 to 24 , as each parameter of shareholders rights is given a zero/one score. Zero indicates an absence of that particular limitation on shareholder rights, whereas a "one" indicates the presence of that limiting provision. Therefore, the lower number indicates greater emphasis on shareholder rights and a relative absence of management entrenchment provisions. A higher number indicates the existence of more provisions limiting shareholder rights and greater presence of management entrenchment. The G-index is available for the 17-year period 1990 to 2006, with eight census years (1990, 1993, 1995, 1998, 2000, 2002, 2004, and 2006). 


\section{METHODOLOGY}

The study analyses the frequency distribution of the G-index scores for (1) the entire IRRC population, (2) the S\&P 500 companies and (3) the six industry groups comprising the ten sectors in the S\&P 500. (See Table 1.) In addition, the study develops and examines basic statistics for each of the eight census years: the mean, median, mode, minimum, maximum and standard deviation. These data are calculated for the IRRC Population and the S\&P 500 companies (as reported in Tables 2 and 6) respectively.

Secondly, this study, in order to analyze trends, regresses the mean G-Index and the standard deviation against time for each of the three classes: the IRRC Population, the S\&P 500 companies and the six industry groups as defined in Table 1. The regression results are set out in Tables 3, 7, 10.

Thirdly, the study examines the frequency distribution of the G-Index by year. G-index scores are classified into three categories, as follows:

- a G-index score between 1-7 is associated with the firms having the highest level of shareholder rights, denoted as GSR.

- a G-index score of between 8 and 10 is associated with firms having mid-range level of shareholder rights denoted as MSR.

- a G-index score of 11 and above categorizes firms with the lowest level of shareholder rights, denoted as LSR.

The above classification is based on the observed mean/median/mode range of $8-10$. The median is consistently at 9 for all 17 years and for all 1,800 firms in the IRRC population.

Fourthly, this study regresses the GSR, MSR and LSR distributions separately against time to derive the respective trend coefficients. This is done for the IRRC population and the S\&P 500 firms, as described in Tables 5 and 9. The study also examines the trends over time in the mean G-Index and their standard deviation for the six industry groups. The regression results are reported in Table 10.

\section{RESULTS AND INTERPRETATION}

\section{IRRC Population}

There is a general perception, and it is also suggested in the previous literature, that shareholder rights have increased in the last 17 years, due to legislative and regulatory to enhance shareholder rights and increase transparency. However, the results in this study do not bear this out. With respect to the IRRC Population G-index (Tables 2 and 3) the mean, median and mode have not changed statistically between 1990 and 2006. In addition, the median G-score has been the same every year pre- and post-2000. Thus, there does not seem to be any over-all increase in shareholder rights during 1990-2006 despite legislative and regulatory efforts at reform towards greater shareholder rights.

Secondly, the standard deviation of the G-index series for the 1,800 companies has declined over time, suggesting that there has been convergence of shareholder rights to a norm that, as noted above, has not changed over the 17-year period. As demonstrated in Figure 2, the standard deviation has declined over time and the decline is statistically very significant. (See Table 3.) 
Figure 2: Trend Analysis of Standard Deviation in the G-Index of the IRRC Population

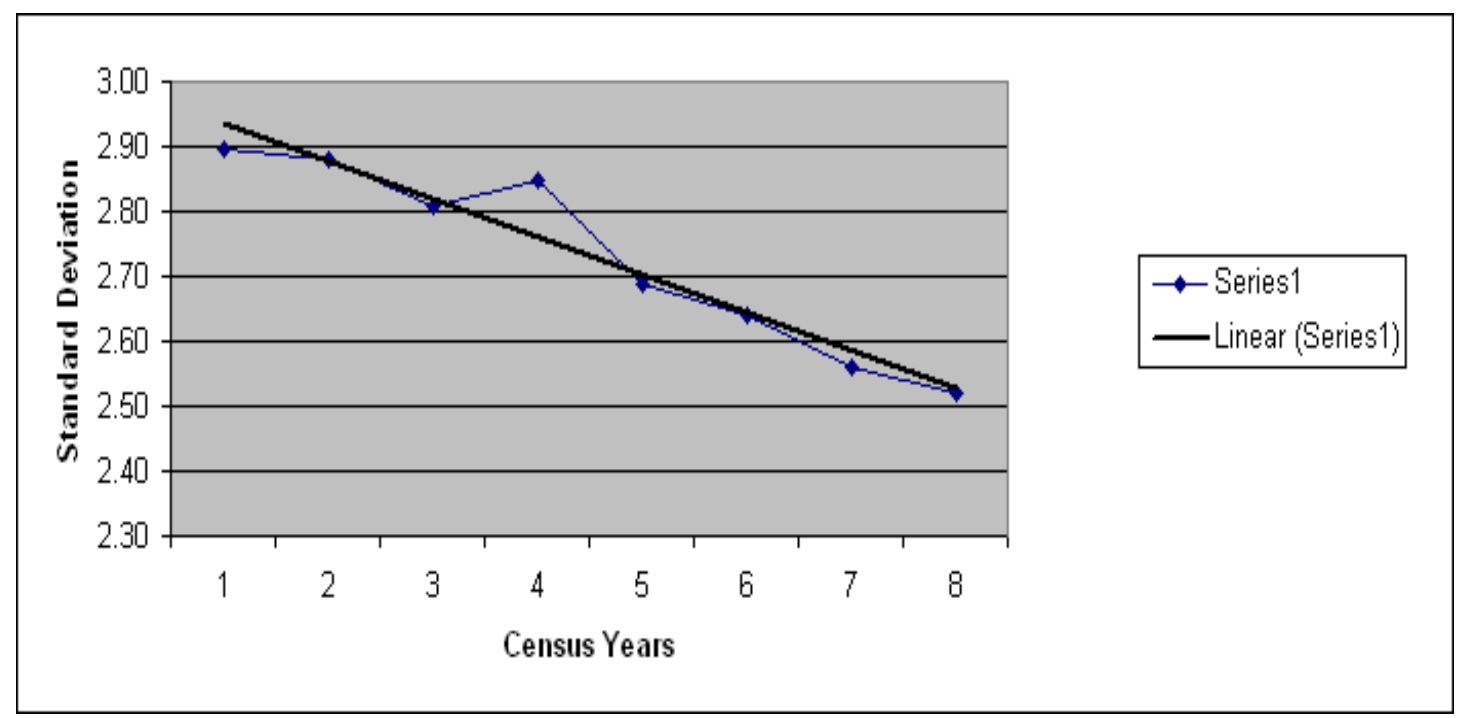

The study investigates the convergence evidence further by examining the tails of the G-Index distribution. This analysis finds that:

- the proportion of firms in the Median Shareholder Rights (MSR) category statistically has increased significantly (Tables 4 and 5).

- the proportion of firms with GSR has not changed statistically over time.

- the proportion of firms in the Lesser Shareholder Rights (LSR) category statistically has declined significantly.

These three results buttress the finding of convergence to a standard/norm in shareholder rights that has not changed over the 17-year period.

\section{The S\&P 500 Companies}

The companies making up the S\&P 500 are primarily large, broadly held firms that incorporate $75 \%$ of the total US market valuation. Statistical analysis reveals that:

- the Mean G-Index for the S\&P 500 has increased significantly, which is in contrast to the finding of "no change" for the entire IRRC population

- the standard deviation has declined significantly, again suggesting convergence to a norm of shareholder rights.

- the proportion of firms in the MSR category has increased significantly.

- the proportion of firms in the GSR category has declined significantly over time.

- there is no significant change in the proportion of firms in the LSR.

- therefore, the source of convergence to the mid-range norm is due to a relative decline of firms in the GSR category

Taken together, these results depict the following:

- $\quad$ overall, shareholder rights have declined amongst the S\&P 500 firms. 
- a large proportion of firms has moved away from the GSR category to conform to the norm of lower shareholder rights.

- $\quad$ there has been a significant increase in the proportion of firms in the LSR shareholder rights category since 2000. The average percentage of firms in the LSR category since 2000 has doubled over the prior period. (See Table 8)

- $\quad$ non-S\&P 500, smaller firms have become more shareholder friendly, whereas the S\&P 500 firms have become much more managerially entrenched.

\section{Analysis By Industry Groups}

An analysis of the data for the six industry groups (See Table 10) highlights the following:

- the mean G-index has gone up significantly in Financials, High-Tech and Utilities, meaning that there has been a lessening of shareholder rights in these industries.

- $\quad$ the standard deviation of the G-Index has declined in five sectors over the 17-year period, again suggesting strong convergence to the norm for these sectors.

- In high-tech and utilities there has been convergence to a norm of reduced shareholder rights.

\section{SUMMARY}

The paper postulates that there is an optimum level of shareholder rights and investigates the long-run trends in corporate governance and the degree of protection of shareholder rights over the 17-year period 1990 2006, using the G-Index for the IRRC population, the S\&P 500 firms, and various industry groups. The results are surprising and contrary to generally held views: The median G-Index for the IRRC Population (1,800 companies) has not changed, but there has been strong convergence towards an average-norm, a one size fits all category of shareholder rights.

For large-cap, S\&P 500 firms, the median G-Index has gone up, suggesting a limiting of shareholder rights among these large firms. In addition, there has been convergence among these firms to a norm of lesser shareholder rights. Therefore, one can infer that more non-S\&P 500, smaller firms have moved towards more transparency and greater shareholder rights, in contrast to the large S\&P 500 firms.

In general, the industry sectors have also demonstrated convergence to the median-norm of corporate governance. The Financials, High-Tech and Utilities sectors have demonstrated a considerable lessening of shareholder rights.

The observed evidence of convergence to a median/norm suggests a constant search by the firms to attain optimality in shareholder rights. The norm for S\&P 500 firms has been toward lesser shareholder rights and greater management entrenchment, whereas the norm for the non-S\&P 500, smaller firms has been towards greater shareholder rights and reduced management entrenchment. Firms seek to balance the benefits with the increase in costs associated with greater shareholder rights. 
Table 1: Industry Sectors and Groups

\begin{tabular}{|c|c|}
\hline The 10 industry Sectors - S\&P 500 Companies & Industry Groups - Research Study \\
\hline Energy 10 & \\
\hline Materials 15 & EMI 10 15 20 \\
\hline Industrials 20 & Consumer 25 30 \\
\hline Consumer Discretionary 25 & Health Care 35 \\
\hline Consumer Staples 30 & Financials 40 \\
\hline Health Care 35 & High-Tech 4550 \\
\hline Financials 40 & Utilities 55 \\
\hline
\end{tabular}

Table 2: Statistics on G-Index by Year -- IRRC Population

\begin{tabular}{|c|c|c|c|c|c|c|c|c|}
\hline & $\mathbf{1 9 9 0}$ & $\mathbf{1 9 9 3}$ & $\mathbf{1 9 9 5}$ & $\mathbf{1 9 9 8}$ & $\mathbf{2 0 0 0}$ & $\mathbf{2 0 0 2}$ & $\mathbf{2 0 0 4}$ & $\mathbf{2 0 0 6}$ \\
\hline Mean & 8.89 & 9.19 & 9.29 & 8.77 & 8.98 & 9.03 & 9.03 & 9.02 \\
\hline Median & 9 & 9 & 9 & 9 & 9 & 9 & 9 & 9 \\
\hline Mode & 10 & 9 & 9 & 10 & 9 & 8 & 8 & 9 \\
\hline Min & 1 & 2 & 2 & 2 & 2 & 1 & 1 & 2 \\
\hline Max & 17 & 17 & 17 & 18 & 19 & 18 & 18 & 18 \\
\hline Std. Dev. & 2.89 & 2.88 & 2.81 & 2.85 & 2.69 & 2.64 & 2.56 & 2.52 \\
\hline
\end{tabular}

Table 3: Regression of Mean and Standard Deviation against Time of IRRC Population

\begin{tabular}{|c|c|c|c|}
\hline & Intercept & Time & R-squared \\
\hline Regression of Mean & 9.05 & -0.0043 & 0.065 \\
\hline Regression of Standard & $(66.56)$ & $(-0.16)$ & 0.97 \\
Deviation & 2.99 & -0.06 & $(-8.99)$ \\
\hline
\end{tabular}

Table 4: Distribution of G-Index Frequencies (percentages) - IRRC Population

\begin{tabular}{|c|c|c|c|c|c|c|c|c|}
\hline Categories* & $\mathbf{1 9 9 0}$ & $\mathbf{1 9 9 3}$ & $\mathbf{1 9 9 5}$ & $\mathbf{1 9 9 8}$ & $\mathbf{2 0 0 0}$ & $\mathbf{2 0 0 2}$ & $\mathbf{2 0 0 4}$ & $\mathbf{2 0 0 6}$ \\
\hline GSR: Class 1-7 & 33.95 & 29.67 & 27.81 & 35.48 & 31.69 & 29.14 & 27.13 & 27.53 \\
\hline MSR: Class 8-10 & 36.06 & 35.95 & 36.83 & 35.68 & 38.95 & 42.29 & 44.38 & 44.57 \\
\hline LSR: Class 11- & 29.99 & 34.38 & 35.36 & 28.84 & 29.36 & 28.56 & 28.49 & 27.90 \\
\hline
\end{tabular}

*GSR denotes Greater Shareholder Rights--it includes companies whose G-Index is less than 8; MSR is the mid-range shareholder rights category and includes companies whose G-Index is 8 through 10; LSR consists of companies with the least shareholder rights and is made up of companies whose G-Index is 11 and above. 
Table 5: Regression of G-Index Proportions for Three Categories against Time - IRRC Population

\begin{tabular}{|c|c|c|c|}
\hline Categories & Intercept & Time & R-squared \\
\hline GSR: Class 1-7 & 33.4 & -0.68 & 0.54 \\
\hline MSR: Class 8-10 & $(15.13)$ & $(-1.56)$ & 0.92 \\
& 32.8 & 1.44 & $(5.76)$ \\
\hline LSR: Class 11-- & $(25.94)$ & -0.76 & 0.65 \\
\hline
\end{tabular}

Table 6: Basic Statistics of G-Index - S\&P 500 Companies

\begin{tabular}{|c|c|c|c|c|c|c|c|c|}
\hline & $\mathbf{1 9 9 0}$ & $\mathbf{1 9 9 3}$ & $\mathbf{1 9 9 5}$ & $\mathbf{1 9 9 8}$ & $\mathbf{2 0 0 0}$ & $\mathbf{2 0 0 2}$ & $\mathbf{2 0 0 4}$ & $\mathbf{2 0 0 6}$ \\
\hline Mean & 9.36 & 9.31 & 9.40 & 9.33 & 9.39 & 9.66 & 9.60 & 9.48 \\
\hline Median & 9 & 9 & 9 & 9 & 9 & 10 & 10 & 9 \\
\hline Mode & 9 & 11 & 11 & 9 & 11 & 11 & 9 & 9 \\
\hline Min & 1 & 2 & 2 & 2 & 2 & 3 & 3 & 3 \\
\hline Max & 16 & 16 & 16 & 16 & 16 & 16 & 16 & 16 \\
\hline Std. Dev. & 2.84 & 2.90 & 2.87 & 2.74 & 2.65 & 257 & 2.47 & 2.48 \\
\hline
\end{tabular}

Table 7: Regression of Mean and Standard Deviation of G-Index against Time S\&P 500 Companies

\begin{tabular}{|c|c|c|c|}
\hline & Intercept & Time & R-squared \\
\hline Regression of Mean & 9.27 & 0.038 & 0.72 \\
\hline Regression of Standard & $(100.24)$ & $(2.53)$ & 0.96 \\
Deviation & 2.99 & -0.07 & $(-8.09)$ \\
\hline
\end{tabular}

Table 8: Distribution of G-Index (Proportions) for Three Categories S\&P 500 Companies

\begin{tabular}{|l|c|c|c|c|c|c|c|c|}
\hline \multicolumn{1}{|c|}{ Categories } & $\mathbf{1 9 9 0}$ & $\mathbf{1 9 9 3}$ & $\mathbf{1 9 9 5}$ & $\mathbf{1 9 9 8}$ & $\mathbf{2 0 0 0}$ & $\mathbf{2 0 0 2}$ & $\mathbf{2 0 0 4}$ & $\mathbf{2 0 0 6}$ \\
\hline GSR: Class 1-7 & 50.00 & 47.37 & 36.84 & 30.77 & 23.08 & 23.33 & 19.35 & 22.58 \\
\hline MSR: Class 8-10 & 35.00 & 36.84 & 42.11 & 57.69 & 46.15 & 36.67 & 48.39 & 51.61 \\
\hline LSR: Class 11- & 15.00 & 15.79 & 21.05 & 11.54 & 30.77 & 40.00 & 32.26 & 25.81 \\
\hline
\end{tabular}

Table 9: Regression of G-Index for Three Categories against Time S\&P 500 Companies

\begin{tabular}{|c|c|c|c|}
\hline Categories & Intercept & Time & R-squared \\
\hline GSR: Class 1-7 & 30.32 & -1.24 & 0.85 \\
\hline MSR: Class 8-10 & $(19.34)$ & $(-3.98)$ & 0.90 \\
\hline LSR: Class 11- & 31.11 & 1.59 & $(5.14)$ \\
& $(19.92)$ & -0.35 & 0.55 \\
\hline
\end{tabular}


Table 10: Analysis of Six Industry Groups

\begin{tabular}{|c|c|c|c|c|c|c|}
\hline $\begin{array}{c}\text { Industry } \\
\text { Groups } \\
\end{array}$ & Regression & of Mean & on Time & Regression & $\begin{array}{c}\text { of Standard } \\
\text { Deviation } \\
\end{array}$ & on Time \\
\hline & Intercept & Time & R-squared & Intercept & Time & R-squared \\
\hline EMI & $\begin{array}{c}9.90 \\
(65.14) \\
\end{array}$ & $\begin{array}{c}0.05 \\
(1.74) \\
\end{array}$ & 0.58 & $\begin{array}{c}2.87 \\
(24.09) \\
\end{array}$ & $\begin{array}{l}-0.057 \\
(-2.42) \\
\end{array}$ & 0.70 \\
\hline Consumer & $\begin{array}{c}9.84 \\
(103.10)\end{array}$ & $\begin{array}{c}-0.03 \\
(-1.44)\end{array}$ & 0.51 & $\begin{array}{c}2.91 \\
(161.22)\end{array}$ & $\begin{array}{l}-0.03 \\
(-7.00)\end{array}$ & 0.94 \\
\hline Health-care & $\begin{array}{c}10.36 \\
(60.83)\end{array}$ & $\begin{array}{l}-0.03 \\
(-0.97)\end{array}$ & 0.34 & $\begin{array}{c}2.61 \\
(25.05)\end{array}$ & $\begin{array}{c}-0.07 \\
(-3.50)\end{array}$ & 0.82 \\
\hline Financials & $\begin{array}{c}8.17 \\
(31.83) \\
\end{array}$ & $\begin{array}{c}0.24 \\
(4.74) \\
\end{array}$ & 0.89 & $\begin{array}{c}2.94 \\
(25.21) \\
\end{array}$ & $\begin{array}{c}-0.02 \\
(-0.66)\end{array}$ & 0.26 \\
\hline High-tech & $\begin{array}{c}8.01 \\
(83.02)\end{array}$ & $\begin{array}{c}0.08 \\
(4.05)\end{array}$ & 0.86 & $\begin{array}{c}3.24 \\
(27.53)\end{array}$ & $\begin{array}{c}-0.16 \\
(-6.843)\end{array}$ & 0.94 \\
\hline Utilities & $\begin{array}{c}7.38 \\
(32.44)\end{array}$ & $\begin{array}{c}0.27 \\
(6.07)\end{array}$ & 0.93 & $\begin{array}{c}2.49 \\
(36.96)\end{array}$ & $\begin{array}{c}-0.05 \\
(-3.78)\end{array}$ & 0.84 \\
\hline
\end{tabular}

\section{APPENDIX A: 24 COMPONENTS OF THE G-INDEX}

\begin{tabular}{|c|c|}
\hline 1. Antigreenmail & $\begin{array}{l}\text { Prohibits Large shareholder from not seeking control of a company in exchange for right to } \\
\text { sell stock back at a premium, unless all shareholders offered same opportunity. }\end{array}$ \\
\hline $\begin{array}{l}\text { 2. Directors Indemnification } \\
\text { Contract }\end{array}$ & $\begin{array}{l}\text { Firm is contractually obligated to pay legal expenses and judgments for suits alleging } \\
\text { misconduct. }\end{array}$ \\
\hline 3. No-Secret Ballot & Allows management to examine individual proxy cards. \\
\hline 4. $\quad$ Blank Check & Allows Board broad latitude in determining shareholder rights. \\
\hline 5. $\quad$ Fair Price & Limits the rights of shareholders to tender shares. \\
\hline 6. $\quad$ Pension Parachutes & Acquirer cannot use surplus pension funds to finance acquisition. \\
\hline $\begin{array}{l}\text { 7. Business Combination } \\
\text { Law }\end{array}$ & Imposes moratorium on M\&A by a large shareholder \\
\hline 8. Golden Parachutes & Lavish severance agreements for senior executives following change in control \\
\hline 9. $\quad$ Poison Pill & Target firm shareholders have right to buy additional shares at a steep discount. \\
\hline 10. Cash-Out Law & Forces acquirer to pay highest recent price to all shareholders. \\
\hline 11. Limit to amend by-Laws & Eliminates or limits the right of shareholders or the Board to amend the by-laws. \\
\hline 12. Severance Agreements & Assures officers of their positions/compensation without reference to changes in control. \\
\hline 13. Compensation Plans & Allows cash out of options or accelerated bonuses in the event of changes in control. \\
\hline 14. Limit to Amend Charter & Eliminates or limits the right of shareholders or the Board to amend the charter. \\
\hline 15. Silver Parachutes & $\begin{array}{l}\text { Similar to golden parachutes, but in this case a large number of employees is eligible in the } \\
\text { event of change in control. }\end{array}$ \\
\hline $\begin{array}{l}\text { 16. Director Indemnification } \\
\text { contracts }\end{array}$ & $\begin{array}{l}\text { Charter and by-laws obligate firm to pay legal expenses and judgments for suits alleging } \\
\text { misconduct against officers and directors. }\end{array}$ \\
\hline $\begin{array}{l}\text { 17. Limits to Special } \\
\text { Meeting }\end{array}$ & $\begin{array}{l}\text { Eliminates or limits ability of shareholders to call a special meeting of the corporate } \\
\text { shareholders. }\end{array}$ \\
\hline 18. Director Liability & Eliminates or limits Directors personal liability for certain acts. \\
\hline 19. Limits Written Consent & Limit ability of management and Board to negotiate M\&A to regularly scheduled meeting. \\
\hline 20. Staggered Board & Only part of the Board is elected each year. \\
\hline 21. Unequal Voting & Long-term shareholders are given more vote than recent buyers. \\
\hline 22. Supermajority & Supermajority of voting shareholders required for M\&A. \\
\hline 23. Directors Duties & Allows Board to consider other constituencies to reject takeover. \\
\hline 24. No-Cumulative Voting & Limits rights of dissident shareholders. Reduces number of independent/dissident $\mathrm{d}$ \\
\hline
\end{tabular}

\section{REFERENCES}

1. Ashbaugh-Staife, Hollis and Collins, Daniel W., and LaFond, Ryan. The Effects of Corporate Governance on Firms' Credit Ratings, Journal of Accounting and Economics, Vol. 42 (1-2), October 2006, 2003-2043. 
2. Ashbaugh-Staife, Hollis and Collins, Daniel W., and LaFond, Ryan. Corporate Governance and the Cost of Equity Capital, December 2004, SSRN.com

3. Bebchuk, Lucian A. Letting Shareholders Set the Rules, Harvard Law Review, Vol. 119, 2006, pp. 17841813.

4. Bebchuk, Lucian A., Cohen, Alma, and Ferrell, Allen. Harvard Law School, John M. Olin Center, Discussion Paper Number 491, 2004.

5. Deutsche Bank, AG. Beyond the Numbers: Corporate Governance: Implications for Investors, 2004.

6. Economist Magazine, The. Keeping Shareholders in their Place, October 13, 2007, p. 69-70

7. Gompers, Paul A., Ishii, Joy L., Metrick, Andrew. Corporate Governance and Equity Prices, Quarterly Journal of Economics, 118 (1), February 2003, 107-155.

8. Heffes, Ellen M. Have the New Rules Improved Boards? Financial Executive, May 2007, pp. 30-35.

9. Hermalin, Benjamin E., Weisbach, Michael S. Transparency and Corporate Governance. NBER Working Paper, 2007.

10. Lehmann, Arik E., Warning, Susanne, and Weigand, Jurgen. Efficient Governance Structures, Corporate Investment and Profitability. GEABA Discussion Paper Number 02-07, EFA 2002 Berlin Meetings.

11. Stout, Lynn A. Corporations Shouldn't Be Democracies, Wall Street Journal, September 27, 2007, page A-17.

12. Weber, Joseph. Discussion of the Effects of Corporate Governance on Firms' Credit Ratings, Journal of Accounting and Economics, Vol. 42 (1-2), October 2006, pp. 245-254.

\section{NOTES}

